\title{
ANALYSIS OF QUALITY OF SERVICE BANDWIDTH MANAGEMENT ON COMPUTER NETWORK USING MIKROTIK RB951Ui-2HnD
}

\author{
I Putu Dicky Indrajaya ${ }^{1}$, Ricky Aurelius Nurtanto Diaz ${ }^{2}$, I Komang Agus Ady Aryanto ${ }^{3}$, I Made Arya \\ Budhi Saputra ${ }^{4}$, Ni Luh Putri Srinadi ${ }^{5}$ \\ S1-Sistem Komputer \\ ITB STIKOM BALI \\ https://www.stikom-bali.ac.id \\ dickyindrajaya@gmail.com 1, ricky@stikom-bali.ac.id 2, komang.aryanto@gmail.com 3; \\ aryabudhi@stikom-bali.ac.id ${ }^{4}$;putri@stikom-bali.ac.id ${ }^{5}$
}

\section{$(*)$ Correspoding Author}

\begin{abstract}
Computer networks are now part of every human activity. The use of computer networks is currently experiencing a significant increase due to the Covid-19 pandemic, however, there are still many problems with computer networks, such as what often happens is the slow pace of computer networks in transferring data caused by limited bandwidth or maximum limits. owned by the computer network. For that, we need a computer network bandwidth management method called the QoS (Quality of Service) method. In this method, a tool called the Mikrotik Routerboard RB951Ui-2HnD is used to conduct this research. In implementing this system the steps are taken starting from data collection, requirements analysis, system design with flowcharts and system depiction using a star topology, then implementation and unit testing on the user or Client, and testing the computer network system on the Mikrotik Router-board. The results of this study will be explained using statistical tables obtained from testing using the Wireshark application.
\end{abstract}

Keywords: Bandwidth, Qos (Quality Of Service), Mikrotik Router-Board RB951Ui-2hnd, Star Topology, Wireshark.

Abstrak - Jaringan komputer kini menjadi bagian dari setiap aktivitas manusia. Penggunaan jaringan komputer saat ini mengalami peningkatan yang cukup signifikan akibat pandemi Covid-19, namun demikian masih banyak permasalahan dengan jaringan komputer, seperti yang sering terjadi adalah lambatnya jaringan komputer dalam mentransfer data yang disebabkan oleh keterbatasan bandwidth atau batas maksimum. dimiliki oleh jaringan komputer. Untuk itu diperlukan suatu metode manajemen bandwidth jaringan komputer yang disebut dengan metode QoS (Quality of Service). Dalam metode ini, alat yang disebut Mikrotik Router-board RB951Ui-2HnD digunakan untuk melakukan penelitian ini. Dalam mengimplementasikan sistem ini dilakukan langkah-langkah mulai dari pengumpulan data, analisis kebutuhan, perancangan sistem dengan diagram alir dan penggambaran sistem menggunakan topologi star, kemudian implementasi dan pengujian unit pada pengguna atau Client, dan pengujian sistem jaringan komputer pada Mikrotik Router- naik. Hasil penelitian ini akan dijelaskan menggunakan tabel statistik yang didapat dari pengujian menggunakan aplikasi Wireshark.

Kata kunci: Bandwidth; Qos (Kualitas Layanan); Mikrotik Router-Board RB951Ui-2hnd, Topologi Star; Wireshark.

\section{INTRODUCTION}

In life at this time, computer networks are already a part of every life of human activity. A computer network is a collection of two or more interconnected computers to conduct data communication (Desmira \& Aribowo, 2016). The connection between two or more computers can occur through wired or wireless media (Without wires) (Nurhuda \& Gunadhy, 2019). The use of computer networks is currently experiencing a significant increase due to the COVID-19 pandemic, many activities and human work must be done at home online to minimize the transmission of diseases caused by the COVID-19 virus outbreak, such as conducting online learning activities (online) using video conference applications, conducting entertainment activities such as playing online games, and conducting live streaming activities for entertainment or seeking information such as watching online seminars or commonly referred to as webinars. In this case, there are still many constraints on the computer network (Khasanah, Pramudibyanto, \& Widuroyekti, 2020) in conducting every activity and human work, a problem that often occurs is the slowness of computer networks (Nitra \& Ryansyah, 2019) in conducting data transfer (Dwiyatno, Putra, \& 
Krisnanigsih, 2015) caused by bandwidth limitations or maximum limits owned by the computer network so that computer networks are not able to quickly serve every activity or human work (Engko \& Usmany, 2020). Therefore, a method of managing computer network bandwidth is required called the QoS (quality of service) method. QoS (Quality of Service) method is a method used to regulate bandwidth usage on a computer network, which is expected to minimize network slowness (Purwahid \& Triloka, 2019) or data density. In QoS method (Quality of Service) provides bandwidth usage limits on each user who uses one computer network fairly and evenly so that the computer network can manage regularly each user activity that varies well without the occurrence of density or traffic in a computer network.

In conducting this research process used some literature or research results that have been made before such as from the journal "Analysis of Quality of Service Hotspot System Performance On Mikrotik Router-board 951Ui-2HnDOn Network Informatics Engineering" proves the results of bandwidth management testing and user management on MikroTik router board hotspot $951 \mathrm{Ui}-2 \mathrm{HnD}$ that has been done, it was obtained that the results of bandwidth management and user management are very well proven by connection tests. Based on Quality of Service testing on MikroTik router-board hotspots 951Ui- 2HnDhas been done, delay value, packet loss and throughput in max download mode, Max upload, streaming, max download Max upload, max streaming download, Max streaming upload, and max download Max upload streaming on 3 trials with 1 Client, 5 Client, and 10 Client obtained good results as well as the average value obtained (Emrul, Yamin, \& Surimi, 2018)

Then from the last journal that researchers referred to the title "Quality of Service Analysis (QoS)Wireless LAN-Based Internet Network On Service" created by Anggita Nindya Wisnu Wardhana, Muh. Yamin, LM Fid Aksara in 2017 with the results of research that has been done during the research can be explained that the service with a bandwidth of $10 \mathrm{Mbps}$ has been good in meeting the needs of its customers. This is evidenced by the QoS parameter value that has been calculated in the test of 2 locations using max download mode and Max upload with 3 trials at the time 1 device is connected, fewer devices are connected and many devices are connected. The Delay value generated in the first 2 locations which are 1 connected device and a few connected devices falls into a very good category where the resulting value does not touch the number $1 \mathrm{~ms}$. But for packet loss parameters in Max download mode when many connected devices decrease to $10 \%$ and fall into the category of

sufficient (Hidayatullah, 2016) even in Max upload mode, the resulting value touches $50 \%$ which means it falls into the bad category at peak times. For Throughput itself is very stable even in busy times and quiet times. This can provide information that internet services are heavily influenced by the large number of users connected massively which eventually makes the QoS value of packet loss parameters decrease, but for Throughput and Delay parameters are not at all affected by the number of users. Also, the time factor affects this service which causes some anomalies in QoS calculation results where it is not guaranteed when the number of users is small, QoS value can be lower than when the number of users is many. This is evidenced in the study that there are anomalies in the Delay and Throughput parameters caused by the time when the connection and calculation of quality of service values (Wardhana, Yamin, \& Aksara, 2017)

With the results of the study analysis of quality of service on computer networks using MikroTik RB951Ui-2HnD that researchers did, using 3 different testing scenarios got results management of bandwidth fairly and evenly on each client, but from these three test scenarios, each client does not occur high packet loss with the consequences of computer network becomes slow. With QoS method (Quality of Sevice)is also expected to be used to facilitate network admin in performing maintenance process on the computer network. This method will be tried to be applied in smallscale computer networks such as computer networks that exist in the home by using MikroTik router-board network device RB951Ui-2HnD as a tool used to manage bandwidth management with QoS(Quality of Service) method.

\section{MATERIALS AND METHODS}

\section{Data Collection}

Data collection is the initial stage of the research method conducted. The method of data collection is done using observation of literature. Observation literature is used for the collection of data and information that can be obtained using the search for materials related to the research conducted.

\section{Needs Analysis}

This stage is a stage that concerns every need in building a system such as data needs and information from data collection results, analyzing the needs of devices and applications or tools, such as LAN cables, router boards, modems, laptops, mobile phones, winboxes, and Wireshark (Watnaya, Muiz, Sumarni, Mansyur, \& Zaqiah, 2020)

\section{System Planning}


System design is a stage that involves creating a schema from the flow from system creation to system testing. An overview of the analysis and design of the system in this study is explained using a flowchart.

\section{Unit Implementation and Testing}

At this stage is the implementation stage of the system based on the results of the system design stage as well as conducting tests on units or devices connected to the network system. At this stage, it takes several devices and applications that will be used in the system manufacturing process, including ASUS X550IU Laptop, Mikrotik Routerboard RB951Ui-2HnD, ZTE F609 Modem, UTP LANCable, Winbox Application, Wireshark Application

\section{System Testing}

The system testing stage is the stage of testing the system that has been created to implement the method of managing Bandwidth uses some hardware and software such as router-board Mikrotik Router-board RB951Ui-2HnD, laptop, winbox to configure bandwidth management on MikroTik. The data collection stage performs performance analysis on each method used, seen through each Client and the test results will be displayed using a static table.

\section{Report Writing}

Report writing is a documentation of all the processes that have been done from the beginning to the end of this study. The report made in this study covers the stages that have been done in the research process. Starting from the background, problem formulation, scope of research, research methods, and writing systematics.

\section{System Overview}

In the overview of the system can be seen some components or devices needed in this computer network system, including $10 \mathrm{Mbps}$ internet service, MODEM ZTE F609, Mikrotik Router-board RB951Ui-2HnD, Winbox application, Wireshark application, laptop, and mobile phone.

In the overview of the system can also be explained that this computer network system includes the internet network obtained from the ISP that is channeled through the modem ZTE F609, then the system configuration is done by the administrator using the winbox application installed on the admin laptop and connected wired with MikroTik router-board RB951Ui-2HnD which is also connected to the modem ZTE F609 to get an internet network. Then the user uses a laptop or mobile phone device to get access to the wirelessly connected internet network using wifi signal from the Router-board MikroTik device RB951Ui-2HnD. The system testing process is done by the administrator using the Wireshark application installed on the admin laptop then the test results can be from the results of the use of the wifi network by the user.

\section{RESULTS AND DISCUSSION}

\section{System Architecture}

The system architecture used is flowchart or flowchart and network topology design using star topology.

\section{Network System Implementation Flowchart}

Flowchart implementation of this network system is a flowchart that explains how the configuration steps of the computer's network system until the network system is ready for use. This network system configuration is done on MikroTik Router-board RB951Ui-2HnD using Winbox tools.
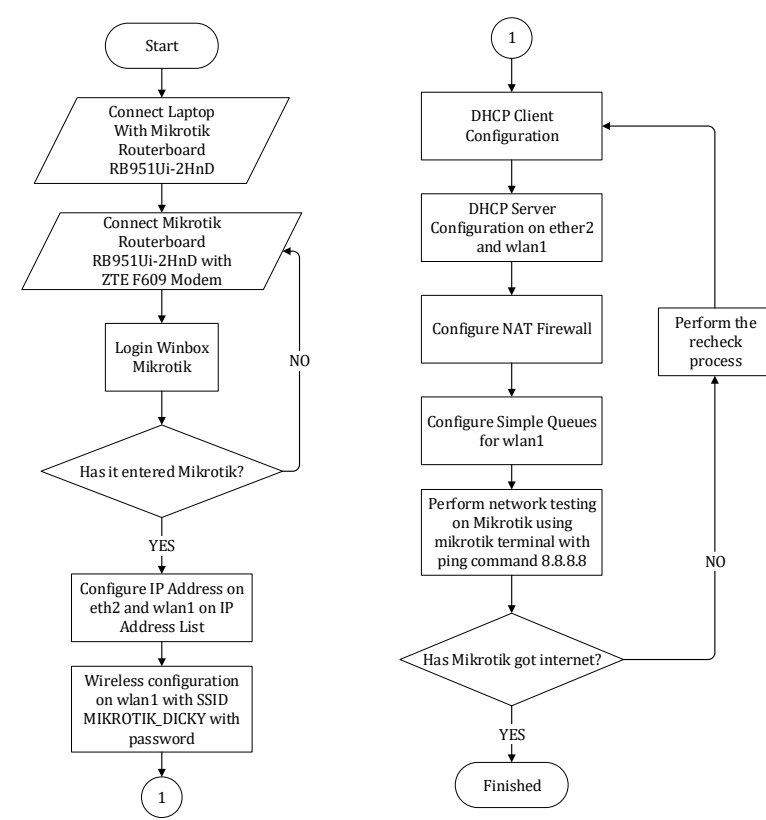

Figure 1 Network Implementation Flowchart

In Figure 1 of the Network Implementation Flowchart, it can be explained that the network system implementation starts from connecting the laptop with Mikrotik Router-board RB951Ui-2HnD, then connect Mikrotik Router-board RB951-2HnD with Modem ZTE F609 to get internet network from ISP, then login to Mikrotik using Winbox tools, the next step is to set the IP Address on the Routerboard port using IP Address list, then set the IP Address on ether2 (IP Address:192.168.20.1/24, Network: 192.168.20.0) and wlan1 (IPAddress: 192.168.19.1/24, Network: 192.168.1 9.0), then configure the wireless network(wifi)on wlan 1 by 
adding SSID= MIKROTIK_DICKY and adding the network password to the Security Profile, then configuring the DHCP Client, then configuring the DHCP Server on ether2 and wlan1, then setting nat on the MikroTik firewall.

Next, do the configuration on Queque Mikrotik, here researchers use Simple Queques to set the amount of bandwidth limit that will be given to client devices connected to the wifi network MIKROTIK_DICKY (wlan1). When you have finished the configuration process, test the internet network using a MikroTik terminal to determine if the MikroTik Router-board has gained internet network access by logging in to the MikroTik terminal, then use the command ping 8.8.8.8 then press ENTER on the keyboard, if you have got an internet network, the Mikrotik router board is also ready to be used by the client device.

\section{Flowchart Connection On Client}

In Figure 2 the connection flowchart on the Client is a flowchart that describes the steps or processes that occur when the client device is connected to the computer network using wireless media.

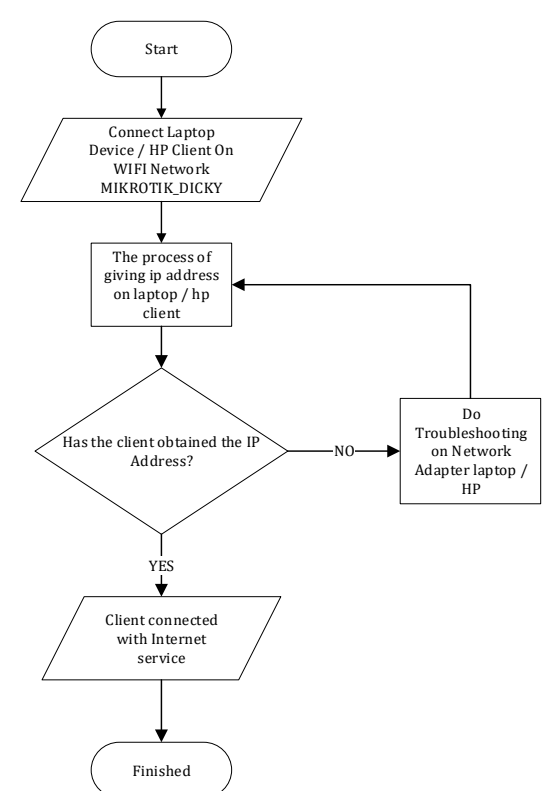

Figure 2 Flowchart Client Connection

In the explanation of the connection flowchart on the Client Figure 2 above, starting from connecting the Client device on the wifi network MIKROTIK_DICKY, then if already connected to the wifi network, make sure each Client gets an IP Address from the MikroTik Router-board (wlan1) by using the command prompt on the Windows operating system with the command IPConfig, using the terminal on the Linux operating system, and if using a mobile phone device can be done by entering the WIFI settings menu click the logo or icon setting on the wifi network $y \rightarrow \rightarrow$ ang connected (MIKROTIK_DICKY) then IP Address can be seen on the IP address tab or IPAddress.

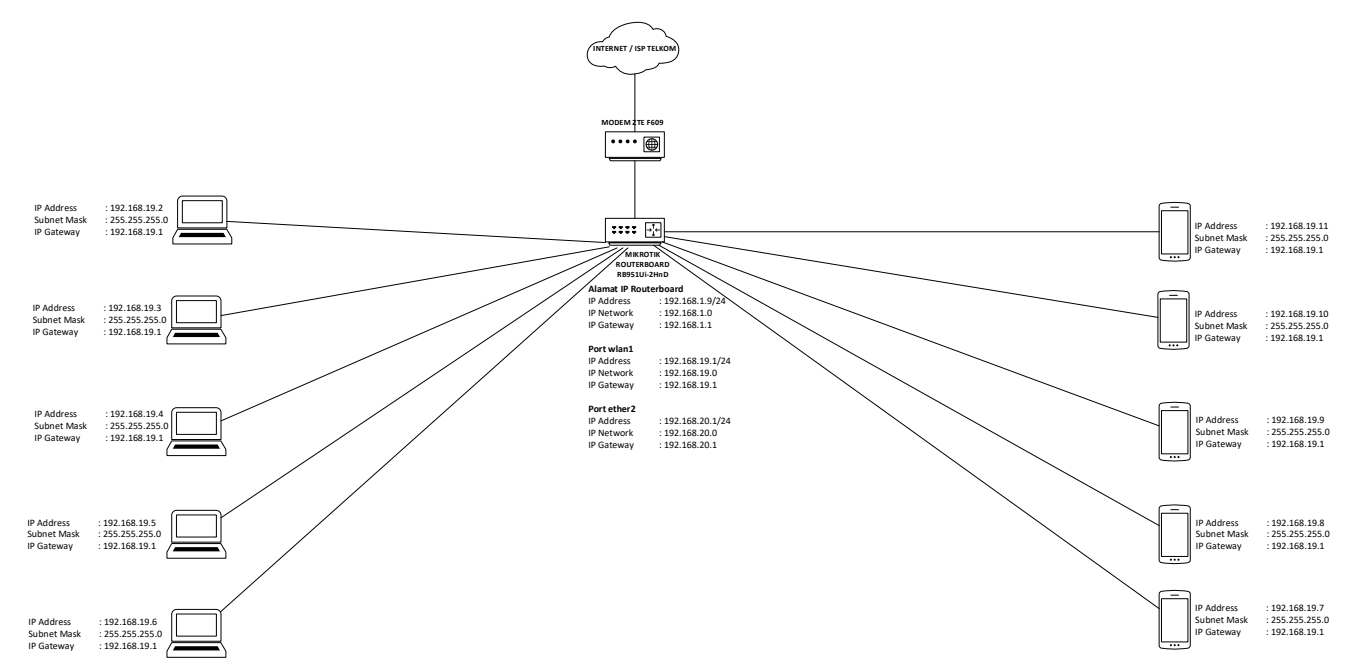

Figure 3 Star Topology

In the depiction of star topology Figure 3 above, each Client device is connected to one Mikrotik Router-board RB951Ui-2HnD device using a wireless network (MIKROTIK_DICKY). Then
Mikrotik Router-board RB951Ui-2HnD is connected with ZTE F609 Modem to get internet service access from ISP. 


\section{Hardware Specifications}

The hardware specifications used by researchers in designing and implementing the system are as follows:

1. Laptop ASUS X550IU : AMD FX-9830P Radeon R7, RAM 16 GB, Harddisk 1 TB, Keyboard dan Mouse

2. Mikrotik Router-board: RB951Ui-2HnD AR9344 600MHz RAM 128 MB, Storage 128 MB, Standard Protocol 802.11 b/g/n, RouterOS License Level 4

3. Modem ZTE F609: One SC/APC port for GPON, Four RJ-45 ports for Gigabit Ethernet interfaces, Two RJ-11 ports for VoIP, One USB3. 2.0 host interfaces. , Wi-Fi 802.11b/g/n (2X2), Button WLAN ON/OFF, WPS, Reset, Power ON/OFF.

\section{Software Specifications Winbox}

The Winbox application or software that researchers use is a remote winbox GUI (Graphical User Interface) to perform the computer network configuration process steps on the Mikrotik Routerboard RB951Ui-2HnD.

\section{Wireshark}

The Wireshark application that researchers use is Wireshark version 3.4.0 which runs on Windows operating systems.

\section{Network System Testing}

Success in testing the network system whether it can be used can be done in several ways, including:

1. In the first stage of testing, to ensure the internet network can run properly, it can be done with a ping command using the terminal on MikroTik os as shown below. If the test results still fail, then the status that appears at the time of the test is Request Timed Out and Destination Host Unreachable.

2. At the second stage of testing, ensuring the internet network can run properly can be done by looking at the configuration on the DHCP Client. On the DHCP Client port, ether1 is connected to the modem, then obtains an IP Address 192.168.1.9/24 from the modem, as well as displaying the bound status. From the results of this test, MikroTik Router-board has certainly gained access to internet services.

In the third stage of testing to ensure the internet network can run properly can conduct tests on wireless or WiFi networks that will be used as a link between the Router-board and the Client device through the port wlan 1 on the MikroTik Router-board. If there is an R on the WiFi Interface tab then wlan 1 is already in running or running status and can already be used client device to get internet service access.

\section{Unit / Client Testing}

In unit / Client testing, parameter calculation of QoS (Quality of service) is performed by calculating throughput, packet loss, delay, jitter. Here are the steps of the QoS parameter calculation process, including:

\section{A. Throughput}

On the capture Figure 3, Wireshark on the Client with IP Address number 192.168.19.3 follows. To find the throughput value, it can be done to know in advance the amount of data sent (bytes), and the time of sending the data (Timespan).

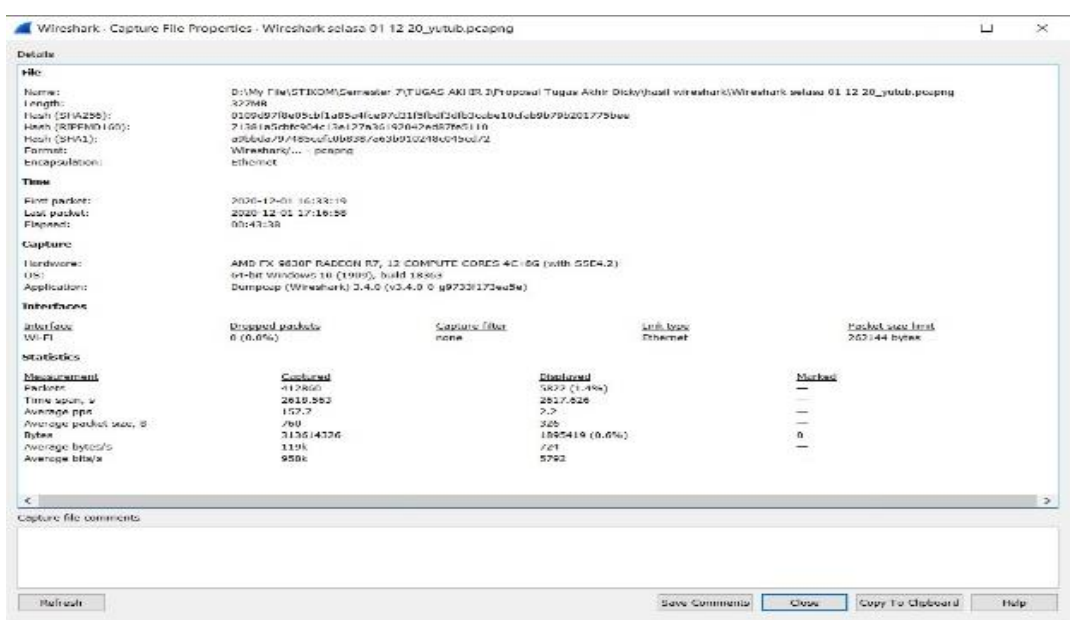

Figure 4Wireshark Capture Results in Calculating Throughput Values

Then it can be seen bytes that can be 313614326 bytes and period that can be 2618.563 s. Then do the calculation process to find the throughput value. 
Throughtput $=\frac{313614326 \text { bytes }}{2618.563 \mathrm{~s}}$
$=119765 \mathrm{Byte} / \mathrm{s}=119.765 \mathrm{~Kb} / \mathrm{s}$
$=119.765 \times 8=958 \mathrm{~Kb} / \mathrm{s} \times 100=95.812 \mathrm{Bit} / \mathrm{s}$
Calculating packet loss can be done by typing the command TCP analysis lost segment, then select the tab statistic and select capture file properties.

\section{B. Packet loss}

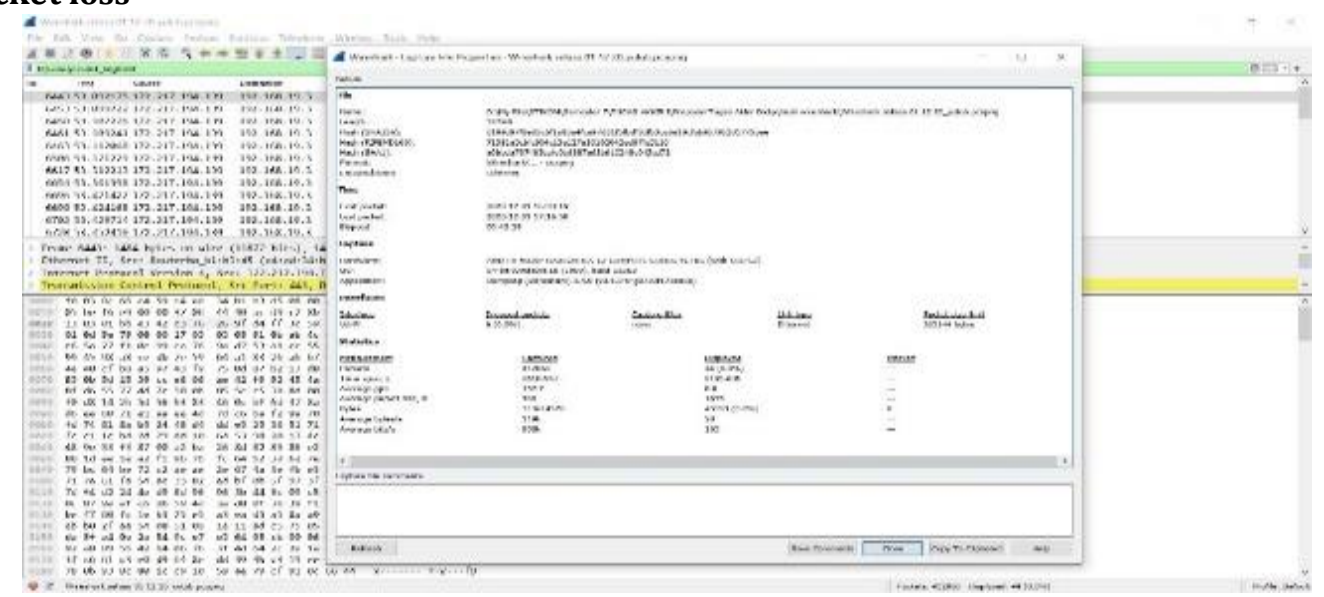

Figure 5Wireshark Capture Results in Calculating Packet loss Value

Then do the calculation process to find packet loss, there are several packets sent as many as 412860 and lost packets as many as 44 .

Packet loss $=\left(\frac{44}{412860}\right) \times 100 \%=0.01 \%$

\section{Delay}

To get the result of Delay, then what will be searched is the average result of Delay that occurs in a network by looking for Delay first by doing the process of subtraction from each Time. Here are some of the values obtained from Time obtained from Wireshark captures. Can be seen in Table 1.

Table 1 Time Cut Table Calculating Delay

\begin{tabular}{clcl}
\hline No & Time 1 & Time 2 & Delay \\
\hline 1 & 0 & 0.009226 & 0.009226 \\
2 & 0.009226 & 0.029279 & 0.020053 \\
3 & 0.029279 & 0.034521 & 0.005242 \\
4 & 0.034521 & 0.064047 & 0.029526 \\
5 & 0.064047 & 0.067935 & 0.003888 \\
6 & 0.067935 & 0.092369 & 0.024434 \\
7 & 0.092369 & 0.118785 & 0.026416 \\
8 & 0.118785 & 0.130395 & 0.01161 \\
9 & 0.130395 & 0.146788 & 0.016393 \\
10 & 0.146788 & 0.14698 & 0.000192 \\
& Total Delay & & 0.987176 \\
\hline \multicolumn{5}{c}{ Average Delay } & & 8.24 \\
\hline
\end{tabular}

If the result of Delay has been obtained, then the Delay result is summed in total to get the total value of Delay $=0.987176$ then, the next step is to find the average value of the total Delay using total Delay / total package received $=0.987176 / 119.765$ $=8.24 \mathrm{~ms}$.

\section{Jitter}

To find the jitter value, a value of each Delay is required. Here are some values obtained from the delay result that can be from the calculation of Time on Wireshark capture results. Can be seen in Table 2.

Table 2 Table Cut Delay Counting Jitter

\begin{tabular}{llll}
\hline No & Delay 1 & Delay 2 & Jitter \\
\hline 1. & 0.009226 & 0.020053 & 0.010827 \\
2. & 0.020053 & 0.005242 & -0.01481 \\
3. & 0.005242 & 0.029526 & 0.024284 \\
4. & 0.029526 & 0.003888 & -0.02564 \\
5. & 0.003888 & 0.024434 & 0.020546 \\
6. & 0.024434 & 0.026416 & 0.001982 \\
7. & 0.026416 & 0.01161 & -0.01481 \\
8. & 0.01161 & 0.016393 & 0.004783 \\
9. & 0.016393 & 0.000192 & -0.0162 \\
10. & 0.000192 & $9.20 \mathrm{E}-05$ & -0.0001 \\
& Total Jitter & 0.008873 \\
\hline \multicolumn{5}{c}{ Average Jitter } & 7.4 \\
\hline
\end{tabular}

The process of calculating jitter starts from doing the reduction process of each Delay, then the result of delay reduction is summed up in its entirety to get the total jitter, then the next step is to find the average of jitter using total jitter / total package received $=0.008873 / 119.765=7.4 \mathrm{~ms}$.

So from the example of calculating the value of throughput, packet loss, Delay, and jitter above, can be seen in Table 3 below.

Table 3 Table Example of QoS Parameter Measurement Result

\begin{tabular}{lllll}
\hline IP Address & $\begin{array}{l}\text { Throughput } \\
(\mathrm{Bit} / \mathrm{s})\end{array}$ & $\begin{array}{l}\text { Packet } \\
\text { loss } \\
(\%)\end{array}$ & $\begin{array}{l}\text { Delay } \\
(\mathrm{ms})\end{array}$ & $\begin{array}{l}\text { Jitter } \\
(\mathrm{ms})\end{array}$ \\
\hline 192.168 .19 .3 & 95.812 & 0.9 & 8.24 & 7.4 \\
\hline
\end{tabular}




\section{Test Scenario 1}

The first test scenario is done with 10 devices /Client. The calculation results can be seen in the following table. Can be seen in Table 4.

Table 4 Ten Clients Test Scenario Results Table

\begin{tabular}{lllll}
\hline IP Address & $\begin{array}{l}\text { Throughput } \\
\text { (Bit/s) }\end{array}$ & $\begin{array}{l}\text { Packet } \\
\text { loss } \\
(\%)\end{array}$ & $\begin{array}{l}\text { Delay } \\
\text { (ms) }\end{array}$ & $\begin{array}{l}\text { Jitter } \\
\text { (ms) }\end{array}$ \\
\hline 192.168 .19 .2 & 83.396 & 0.9 & 92 & 23.3 \\
192.168 .19 .3 & 100.261 & 0.10 & 129 & 4.4 \\
192.168 .19 .4 & 125.327 & 0.79 & 320 & 36.6 \\
192.168 .19 .5 & 135.344 & 12.44 & 383 & 13.6 \\
192.168 .19 .6 & 83.396 & 5.44 & 377 & 37.1 \\
192.168 .19 .7 & 3.163 & 1.8 & 92 & 92.9 \\
192.168 .19 .8 & 238.783 & 1 & 342 & 18.6 \\
192.168 .19 .9 & 158.808 & 0.95 & 143 & 531 \\
192.168 .19 .10 & 158.808 & 1.1 & 53.2 & 53.2 \\
192.168 .19 .11 & 42.320 & 0.9 & 11.8 & 2.4 \\
\hline
\end{tabular}

\section{Test Scenario 2}

The second test scenario is done with 5 devices /Client. The calculation results can be seen in the table 5 below.

Table 5 Five Clients Test Scenario Result Table

\begin{tabular}{lllll}
\hline IP Address & $\begin{array}{l}\text { Throughput } \\
\text { (Bit/s) }\end{array}$ & $\begin{array}{l}\text { Packet } \\
\text { loss } \\
(\%)\end{array}$ & $\begin{array}{l}\text { Delay } \\
\text { (ms) }\end{array}$ & $\begin{array}{l}\text { Jitter } \\
\text { (ms) }\end{array}$ \\
\hline 192.168 .19 .3 & 95.812 & 0.9 & 8.24 & 7.4 \\
192.168 .19 .4 & 119.639 & 3.6 & 66 & 5.6 \\
192.168 .19 .5 & 115.647 & 0.9 & 6.2 & 6.6 \\
192.168 .19 .6 & 58.861 & 0.9 & 13.1 & 13 \\
192.168 .19 .7 & 75.890 & 0.1 & 13.3 & 13.3 \\
\hline
\end{tabular}

\section{Test Scenario 3}

The third test scenario is done with 2 devices /Client. The calculation results can be seen in the following table 6 .

Table 6 Two Clients Test Scenario Results Table

\begin{tabular}{lllll}
\hline IP Address & $\begin{array}{l}\text { Throughput } \\
\text { (Bit/s) }\end{array}$ & $\begin{array}{l}\text { Packet } \\
\text { loss } \\
(\%)\end{array}$ & $\begin{array}{l}\text { Delay } \\
\text { (ms) }\end{array}$ & $\begin{array}{l}\text { Jitter } \\
\text { (ms) }\end{array}$ \\
\hline 192.168 .19 .3 & 95.812 & 0.9 & 8.24 & 7.4 \\
192.168 .19 .4 & 238.783 & 0.9 & 3.2 & 3.2 \\
\hline
\end{tabular}

\section{Test Analysis}

From the results of this test analysis, it can be explained that each test scenario has different results. With this result can be determined the value of the parameters by the QoS standard (Quality of Service) on the computer network using the service $10 \mathrm{Mbps}$.

\section{Clients Scenario Testing Analysis}

The results of the test analysis using scenario 10 Clients can be concluded, if the internet network is used by 10 Clients, it can be used well but the resulting Delay is very bad and still, the occurrence of packet loss is quite a lot, consequently, there is still a slow internet network on the Client in accessing the internet. The process of recording or capturing packet data is done in sunny weather conditions and this data collection time is done on November 22, 2020, starting from 10.00 - 14.00 WITA.

\section{Clients Scenario Testing Analysis}

The results of the test analysis using scenario 5 Clients can be concluded, if the internet network is used by 5 Clients, it can be used well because the Client does not feel a slow network and packet loss a lot as in the test analysis results using scenario 10 Clients. The process of recording or capturing packet data is done in sunny weather conditions and this data collection time is done on November 22, 2020 , starting from $10.00-14.00$.

\section{Scenario 2 Clients Testing Analysis}

The results of the test analysis using scenario 2 Clients can be concluded, if the internet network is used by 2 Clients, it can be used well because the Client does not feel a slow network and packet loss a lot as in the test analysis results using scenario 10 Clients and scenario 5 Clients.

The process of recording or capturing packet data is done in sunny weather conditions and this data collection time is done on December 2, 2020, starting from $11.00-13.00$.

\section{CONCLUSION}

Based on the discussion in the previous chapter, several conclusions have been obtained including the analysis of quality of service on computer networks using MikroTik router-board rb951Ui-2HnD by using 3 test scenarios that produce the value of QoS parameters (Quality of service) which refers to the standard parameters of throughput, packet loss, delay, and jitter. From the QoS parameter value (Quality of Service) obtained from the capture packet results when the Client conducts video conferences, using live streaming service applications, and playing online games using Wireshark applications. Then from the test results that the researchers have done with 3 scenarios consisting of the first test scenario involving 10 Clients, the second test scenario involving 5 Clients, and the third test scenario involving 2 Clients. In the first test scenario involving 10 Clients, the average value obtained from the Simple Queque method on MikroTik Router-board RB951Ui-2HnD with max limit upload 3Mbps and Max download limit of 3 Mbps based on TIPHON category standard for Throughput parameter index is 4 ("Very Good"), Packet loss parameter index is 4 ("Very Good"), Delay parameter index is 1 ("Bad"), jitter parameter index is 3 ("Good"). From the results of this test, there is still a very bad Delay, so there is still a slow 
internet network on each Client, but packet loss or packets are lost on each Client almost nothing (Engko \& Usmany, 2020). Then on the second scenario test, involving 5 Client average value obtained from Simple Queque method on Mikrotik Router-board RB951Ui-2HnD with Max upload limit of $3 \mathrm{Mbps}$ and Max download limit of 3Mbps based on TIPHON category standard for Throughput parameter index is 3 ("Good"), Packet loss parameter index is 4 ("Very Good"), Delay parameter index is 4 ("Very Good"), jitter parameter index is 3 ("Good"). From the results of this test, the value of throughput can still be said to be good because the transfer rate is still stable and packet loss occurs very little, and delays that occur can still be said not to affect the speed of the data transfer. Then in the third test scenario involves 2 Client average value obtained from the Simple Queque method on Mikrotik Router-board RB951Ui-2HnD with Max upload limit of 3Mbps and Max download limit of 3Mbps based on TIPHON category standard for index Throughput parameters are 4 ("Very Good") and ("Good"), packet loss parameter index is 4 ("Very Good"), Delay parameter index is 4 ("Very Good"), jitter parameter index is 3 ("Good"). From the results of this test, the value of throughput can still be said to be good because the transfer rate is still stable and packet loss that occurs very little, a delay that occurs can be said not to affect the speed of data transfer. From the test results using 3 test scenarios, it can be said that internet service with a maximum limit of $10 \mathrm{Mbps}$, can already meet the quality of service measurement standards based on TIPHONE category standards.

\section{REFERENCE}

Desmira, D., \& Aribowo, D. (2016). Analisis Jaringan Lan Dan Wlan Pltu Pada Pt. Pembangkitan Jawa Bali Unit Muara Karang Jakarta. PROSISKO: Jurnal Pengembangan Riset Dan Observasi Sistem Komputer, 3(2), 33-41. Retrieved from https://ejurnal.lppmunsera.org/index.php/PROSISKO /article/view/24/

Dwiyatno, S., Putra, G. W., \& Krisnanigsih, E. (2015). Penerapan Ospf Routing, De-Militarized Zone, Dan Firewall Pada Mikrotik Routerboardtm Dinas Komunikasi Dan Informatika Depok. Sistem Informasi, 2, 59-67. Retrieved from http://www.areeurbane.apat.it/site/itIT/Archivio/Pubblicazioni/Pubblicazioni/co ntributi_integrali_2006.html
Emrul, A., Yamin, M., \& Surimi, L. (2018). Analisis Quality of Service (QoS) Kinerja Sistem Hotspot Pada Routerboard Mikrotik 951Ui2HnD Pada Jaringan Teknik Informatika. SemanTIK, 3(2), 87-94. Retrieved from http://ojs.uho.ac.id/index.php/semantik/arti cle/view/3438

Engko, C., \& Usmany, P. (2020). Dampak Pandemi Covid-19 Terhadap Proses Pembelajaran Online. Jurnal Akuntansi, 6(1), 22-38.

Hidayatullah, M. S. (2016). Analisis Perbandingan Quality Of Service (Qos) Firmware Original TlWr841nd Dengan Firmware Openwrt Berbasis Open Source. Jurnal Ilmiah Teknologi Infomasi Terapan, 2(2), 150-156. https://doi.org/10.33197/JITTER.VOL2.ISS2. 2016.102

Khasanah, D. R. A. U., Pramudibyanto, H., \& Widuroyekti, B. (2020). Pendidikan Dalam Masa Pandemi Covid-19. Jurnal Sinestesia, 10(1), 41-48.

Nitra, R. O., \& Ryansyah, M. (2019). Implementasi Sistem Keamanan Jaringan Menggunakan Firewall Security Port pada Vitaa Multi Oxygen. Jurnal Sistem Dan Teknologi Informasi (JUSTIN), $7(1)$, 52. https://doi.org/10.26418/justin.v7i1.29979

Nurhuda, A., \& Gunadhy, E. (2019). Rancang Bangun Portal Jaringan Unit Keshatan di Kabupaten Garut Online. Jurnal Algoritma, 16(1), 39-50. https://doi.org/10.33364/algoritma/v.161.39

Purwahid, M., \& Triloka, J. (2019). Analisis Quality of Service (QOS) Jaringan Internet Untuk Mendukung Rencana Strategis Infrastruktur Jaringan Komputer Di SMK N I Sukadana. JTKSI, 2(3), 100-109. Retrieved from https://ojs.stmikpringsewu.ac.id/index.php/j tksi/article/view/778/

Wardhana, A. N. W., Yamin, M., \& Aksara, L. F. (2017). Analisis Quality of Service (QoS) jaringan internet berbasis wireless LAN pada layanan Indihome. SemanTIK, 3(2), 49-58. Retrieved

from http://ojs.uho.ac.id/index.php/semantik/arti cle/view/3200

Watnaya, A. K., Muiz, M. H., Sumarni, N., Mansyur, A. S., \& Zaqiah, Q. Y. (2020). Pengaruh Teknologi Pembelajaran Kuliah Online Di Era Covid-19 Dan Dampaknya Terhadap Mental Mahasiswa. EduTeach: Jurnal Edukasi Dan Teknologi Pembelajaran, 1(2), 153-165. https://doi.org/10.37859/eduteach.v1i2.198 7 